Article

\title{
Leachability of Arsenic and Heavy Metals from Mine Tailings of Abandoned Metal Mines
}

\section{Mihee Lim, Gi-Chun Han, Ji-Whan Ahn *, Kwang-Suk You and Hyung-Seok Kim}

Korea Institute of Geoscience and Mineral Resources (KIGAM), 92 Gwahang-no, Yuseong-gu, Daejeon 305-350, Korea; E-Mails: limmh@paran.com (M.L.); hsue@dreamwiz.com (G-C.H.); youks@kigam.re.kr (K-S.Y.); hskim@kigam.re.kr (H-S.L.)

* Author to whom correspondence should be addressed; E-Mail: ahn1305@paran.com; Tel.: +82-42-868-3578; Fax: +82-42-861-3990.

Received: 31 August 2009 / Accepted: 14 November 2009 / Published: 17 November 2009

\begin{abstract}
Mine tailings from an abandoned metal mine in Korea contained high concentrations of arsenic (As) and heavy metals [e.g., As: 67,336, Fe: 137,180, Cu: 764, $\mathrm{Pb}: 3,572$, and $\mathrm{Zn}: 12,420(\mathrm{mg} / \mathrm{kg})$ ]. US EPA method 6010 was an effective method for analyzing total arsenic and heavy metals concentrations. Arsenic in the mine tailings showed a high residual fraction of $89 \%$ by a sequential extraction. In Toxicity Characteristic Leaching Procedure (TCLP) and Korean Standard Leaching Test (KSLT), leaching concentrations of arsenic and heavy metals were very low [e.g., As (mg/L): 0.4 for TCLP and 0.2 for KSLT; cf. As criteria (mg/L): 5.0 for TCLP and 1.5 for KSLT].
\end{abstract}

Keywords: mine tailings; abandoned mines; arsenic (As); heavy metals; sequential extraction; EPA method 6010; Toxicity Characteristic Leaching Procedure (TCLP)

\section{Introduction}

Mining operations generally produce many types of mine wastes, including mine tailings, waste rock and slag. Mine tailings out of those, in particular, act as a main source of environmental contamination [1]. Arsenic (As) and heavy metals may be released from the mine wastes to the ground 
and surface water systems, as well as the geological environment due to their solubility and mobility [2].

Mine tailings often contain sulfide minerals such as pyrite $\left(\mathrm{FeS}_{2}\right)$, arsenopyrite ( $\left.\mathrm{FeAsS}\right)$, galena $(\mathrm{PbS})$, chalcopyrite $\left(\mathrm{CuFeS}_{2}\right)$, and sphalerite $((\mathrm{Fe}, \mathrm{Zn}) \mathrm{S})$. Oxidation, dissolution, precipitation, adsorption, and desorption mainly occur in mine tailings exposed to the air. Oxidation of sulfide minerals results in contamination of the surrounding soil and groundwater by allowing release of As and heavy metals in sulfide-bearing minerals [3-5]. Furthermore, As and heavy metals from mine tailings may cause fatal diseases in humans through crops and water due to the characteristic easy accumulation in internal organs [6].

Most of the mines in Korea have been closed since the 1970s due to various changes in the structure of the domestic industry. In investigations on actual conditions of 219 abandoned metal mines until 2006 among 936 ones nationwide, it has been revealed that $\mathrm{As}$ and heavy metals (e.g., $\mathrm{Cu}, \mathrm{Pb}$ and $\mathrm{Cd}$ ) concentrations in mine wastes at 139 abandoned metal mines (about 63\%) are higher than the current Korean soil contamination criteria [7]. The criteria include both warning and acting criteria. In particular, the acting criteria express a serious pollution state needing control action such as the suspension of land development, owing to concerns on human health and growth of animals and plants. On the other hand, the warning criteria are $40 \%$ values of the action criteria and its objective is to prevent more serious soil contamination than the current state.

Based on the national investigation, among several abandoned mines it is well known that the wastes of the Kumho mine, located in Bonghwa, Kyoungbuk province, Korea, contain high concentrations of both $\mathrm{As}$ and heavy metals. The mine had generally produced $\mathrm{Au}, \mathrm{Ag}, \mathrm{Cu}, \mathrm{Pb}, \mathrm{Zn}$, and Mn, and in particular produced about 140,000 tons of Mn until 1990s and 10,000-20,000 tons of $\mathrm{Zn}$ ore until early 2000s, but it was closed in 2001. A large amount of mine wastes including mine tailings, slag, and waste rock was also produced by the mining operation. Also, flood damages and ground subsidence have occurred at the mine several times because it was not equipped with any facility for the prevention of the damage (Figure 1). Therefore, the government recently started out to restore nearby water and soil environment of the mine. This abandoned mine, in this study, was selected for a sampling site to understand their characteristics and to estimate the application possibility of our technology, which will be explained below, to the ongoing restoration site.

Figure 1. Kumho mine located in Bonghwa, Korea.

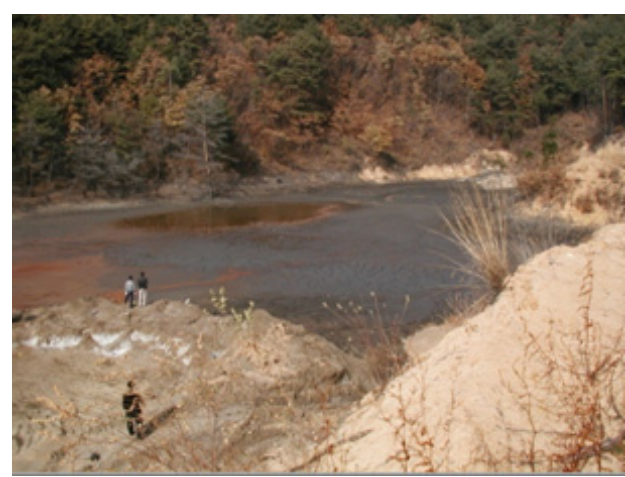

(a) Flood damage site

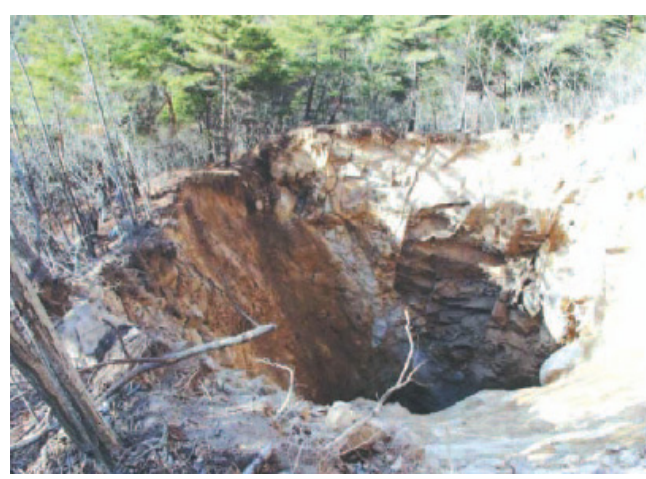

(b) Ground subsidence site 
In order to treat and prevent environmental pollution by mine wastes from abandoned metal mines, various treatment technologies such as soil washing [8], chemical reduction/oxidation [9], solidification/stabilization [10], bioremediation [11], etc. have been applied to contaminated sites. Our future research will be, in particular, focused on solidification/stabilization of heavy metals in the mine wastes and the soil by carbonation technology using $\mathrm{Ca}$ material and $\mathrm{CO}_{2}$ gas, which is our ultimate research goal [12-14]. For the future study, current investigation on contamination level and leaching potential of arsenic and heavy metals from the mine tailings would be a preliminary work for determining whether we can apply the carbonation to the specific mine tailings treatment.

In this study, three standard methods were used for determining total concentrations of As and heavy metals ( $\mathrm{Fe}, \mathrm{Cu}, \mathrm{Pb}, \mathrm{Mn}, \mathrm{Cr}, \mathrm{Cd}$, and $\mathrm{Zn}$ ) in mine tailings as follows: US EPA Standard Method (EPA method 6010), Korean Soil Environment Standard Test (KST for soil), and Korean Waste Standard Test (KST for waste). In addition, chemical combination characteristic of As in the mine tailings was analyzed by chemical extraction method of six steps. Leaching potential of As and heavy metals from the mine tailings was examined by both Toxicity Characteristic Leaching Procedure (TCLP; EPA method 1311) and Korean Standard Leaching Test (KSLT).

\section{Experimental}

A sampling of mine tailings was performed at the Kumho mine in April 2009. A small pile of the mine tailings was placed near a mine-head without any cover for the prevention of their loss. About $20 \mathrm{~kg}$ of the mine tailings were collected from the surface of the pile using a shovel. Mine tailings characteristics according to the pile depth was not considered in this study. The sample was put into plastic bags in the field. After transferring to our laboratory, the sample was sieved through a $5 \mathrm{~mm}$-sieve, homogenized, and dried at $40{ }^{\circ} \mathrm{C}$ for two days. The sample was then stored in desiccators during the whole experimental period.

Several tests were performed to investigate the characteristics of the sample. All tests were repeated on two different days. Firstly, pH (520A, Orion) of the sample was measured after shaking at $100 \mathrm{rpm}$ for an hour [wet sample: water $=1: 10(\mathrm{wt}: \mathrm{wt})$ ]. Water content, loss on ignition (LOI), and organic carbon content were also examined as methods that form part of the KST for waste [15]. Concentrations of anions in the mine tailings were analyzed using ion chromatography (IC; ICS 2000). The solution used in anion analysis was same as that in $\mathrm{pH}$ analysis. Chemical composition of the mine tailings was analyzed using an X-ray diffraction analyzer (XRD; X'pert, Phillips).

Total concentrations of As and heavy metals ( $\mathrm{Fe}, \mathrm{Cu}, \mathrm{Pb}, \mathrm{Mn}, \mathrm{Cr}, \mathrm{Cd}$, and $\mathrm{Zn}$ ) in the sample were determined. Based on results of previous researches indicating that concentrations of heavy metals can be different according to the testing methods used, we also applied three methods to our experiments: EPA method 6010, KST for soil, and KST for waste [15-17]. Both EPA method 6010 and KST for waste are methods involving digestion of soil, sediment, and sludge with $\mathrm{HNO}_{3}, \mathrm{HCl}$, and $\mathrm{H}_{2} \mathrm{O}_{2}$ (no addition in KST for waste) on a hot plate, but the specific details of the two methods are somewhat different, as shown in Table 1. KST for soil is, on the other hand, a leaching method with $0.1 \mathrm{~N} \mathrm{HCl}$ (for $\mathrm{Cd}, \mathrm{Cu}$, and $\mathrm{Pb}$ ) or $1 \mathrm{~N} \mathrm{HCl}$ (for $\mathrm{As}$ ) at $100 \mathrm{rpm}$ for an hour. In the three methods, final suspended solution was filtrated with $0.45 \mu \mathrm{m}$-membrane filter. Each filtrated solution was acidified $(\mathrm{pH}<2)$ 
with two drops of $60 \% \mathrm{HNO}_{3}$ and was analyzed using an atomic absorption spectrometer (AAS; AA-6800, Shimadzu).

Table 1. Comparison of US EPA method 6010 and Korean Standard Test (KST) for soil and waste.

\begin{tabular}{|c|c|c|c|}
\hline & EPA method 6010 & KST for soil & KST for waste \\
\hline $\begin{array}{l}\text { Definition and } \\
\text { purpose }\end{array}$ & $\begin{array}{l}\text { To determine } \\
\text { concentrations of trace } \\
\text { elements, including } \\
\text { metals, in groundwater, } \\
\text { soils, sludges, sediments } \\
\text { and other solid wastes }\end{array}$ & $\begin{array}{l}\text { To determine if the soil is } \\
\text { contaminated by either } \\
\text { inorganic or organic } \\
\text { environmental contaminants } \\
\text { over the regulation level by } \\
\text { Korean soil preservation act }\end{array}$ & $\begin{array}{l}\text { To determine if a waste is } \\
\text { hazardous over the regulation } \\
\text { level by Korean waste } \\
\text { management act and to } \\
\text { determine concentrations of } \\
\text { contaminants in a waste }\end{array}$ \\
\hline Target samples & Sediment, sludge, and soil & Soil & $\begin{array}{l}\text { Wastes including low content } \\
\text { of organic matter and metallic } \\
\text { oxide, hydroxide, and sulfide }\end{array}$ \\
\hline Target elements & $\begin{array}{l}\mathrm{As}, \mathrm{Ag}, \mathrm{Al}, \mathrm{Ba}, \mathrm{Be}, \mathrm{Ca}, \\
\mathrm{Co}, \mathrm{Cr}, \mathrm{Cu}, \mathrm{Fe}, \mathrm{K}, \mathrm{Mg}, \\
\mathrm{Mn}, \mathrm{Mo}, \mathrm{Na}, \mathrm{Ni}, \mathrm{Pb}, \mathrm{Se}, \\
\mathrm{Zn}, \mathrm{Tl}, \mathrm{V}\end{array}$ & $\mathrm{Cd}, \mathrm{Cu}, \mathrm{Pb}, \mathrm{As}$ & $\mathrm{As}, \mathrm{Pb}, \mathrm{Cd}, \mathrm{Cu}, \mathrm{Cr}$ \\
\hline Sample amount & $2 \mathrm{~g}$ & $10 \mathrm{~g}$ & Unspecified \\
\hline Reagents & $\begin{array}{l}1: 1 \mathrm{HNO}_{3}, 30 \% \mathrm{H}_{2} \mathrm{O}_{2} \text {, and } \\
\text { concentrated } \mathrm{HCl}\end{array}$ & $\begin{array}{l}0.1 \mathrm{~N} \mathrm{HCl} \text { (for } \mathrm{Cd}, \mathrm{Cu} \text {, and } \\
\mathrm{Pb} \text { ) } \\
1 \mathrm{~N} \mathrm{HCl} \text { (for } \mathrm{As} \text { ) }\end{array}$ & $\mathrm{HNO}_{3}$ and $\mathrm{HCl}(1+1)$ \\
\hline Reaction & $\begin{array}{l}\text { Heating (under boiling } \\
\text { point) }\end{array}$ & $\begin{array}{l}\text { Shaking ( } 100 \mathrm{rpm} \text { for } 1 \mathrm{hr} \text { at } \\
\left.30^{\circ} \mathrm{C}\right)\end{array}$ & Heating (under boiling point) \\
\hline $\begin{array}{l}\text { Total reaction } \\
\text { time }\end{array}$ & About $3.5 \mathrm{hr}$ & $1 \mathrm{hr}$ & About $2 \mathrm{hr}$ \\
\hline $\begin{array}{l}\text { Final solution } \\
\text { volume (with } \\
\text { water addition) } \\
\end{array}$ & $100 \mathrm{~mL}$ & $50 \mathrm{~mL}$ & $100 \mathrm{~mL}$ \\
\hline
\end{tabular}

A sequential extraction was also performed to operationally fractionate As in the solid materials to evaluate its potential effects [18]. A method developed by Herreweghe et al. [19] was applied in this

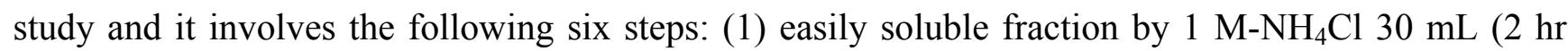
shaking), (2) extractable fraction by $0.5 \mathrm{M}-\mathrm{NH}_{4} \mathrm{~F} 30 \mathrm{~mL}$ (15 hr shaking), (3) extractable fraction by $0.1 \mathrm{M}-\mathrm{NaOH} 30 \mathrm{~mL}$ (17 hr shaking), (4) reducible fraction by $0.5 \mathrm{M}$-sodium citrate $30 \mathrm{~mL}$ and $1 \mathrm{M}-\mathrm{NaHCO}_{3} 2.5 \mathrm{~mL}$ while adding $0.5 \mathrm{~g}-\mathrm{Na}_{2} \mathrm{~S}_{2} \mathrm{O}_{4} \cdot 2 \mathrm{H}_{2} \mathrm{O}$ (15 min heating), (5) acid soluble fraction by $0.25 \mathrm{M}-\mathrm{H}_{2} \mathrm{SO}_{4} 30 \mathrm{~mL}$ (12 hr shaking), and 6) residual fraction by concentrated $\mathrm{HCl} 4 \mathrm{~mL}, \mathrm{HNO}_{3} 2 \mathrm{~mL}$ and HF $2 \mathrm{~mL}$ (heating until half dry). In this test, $0.5 \mathrm{~g}$ of the mine tailings was placed in a $100 \mathrm{~mL}$ beaker. At each step, the suspension was filtrated with a $0.45 \mu \mathrm{m}$-membrane filter. The filtrate was used for arsenic analysis and the solid on the filter paper was used in the next step after washing with $20 \mathrm{~mL}$ of ultra-pure water. Then, the water used in washing was discharged.

Lastly, leaching concentrations of arsenic and heavy metals from the mine tailings were evaluated by both TCLP and KSLT [15,20]. The purpose of TCLP is to determine if a waste meets a hazardous 
waste code listed in 40CFR (Code of Federal Regulations) Part 26 under Resource Conservation and Recovery Act (RCRA), and that of KSLT is to determine if a waste is a hazardous matter specified over the regulation level of Korean waste management act or which landfill method is proper for a waste. The comparison between the two methods is shown in Table 2. In TCLP, fluid \#1 was prepared by adding $5.7 \mathrm{~mL}$ of glacial acetic acid and $64.3 \mathrm{~mL}$ of $1 \mathrm{~N} \mathrm{NaOH}$ to $500 \mathrm{~mL}$ of ultra-pure water and diluting total volume into $1 \mathrm{~L}$ with water, and fluid \#2 was prepared by the same method as fluid \#1 but without adding $1 \mathrm{~N} \mathrm{NaOH}$. To select a solution between \#1 and \#2, pH of the mine tailings was measured by shaking $5 \mathrm{~g}$ of mine tailings with $96.5 \mathrm{~mL}$ for $5 \mathrm{~min}$. Then, if $\mathrm{pH}$ of the solution is $<5.0$, fluid $\# 1$ is selected, otherwise following additional step is needed: the solution is acidified with $3.5 \mathrm{~mL}$ of $1 \mathrm{~N} \mathrm{HCl}$ and heated at $50^{\circ} \mathrm{C}$ for $10 \mathrm{~min}$. After cooling, if $\mathrm{pH}$ of the acidified solution is $<5.0$, fluid $\# 1$ is selected, otherwise fluid \#2.

Table 2. Comparison of Toxicity Characteristic Leaching Procedure (TCLP; EPA method 1311) and Korean Standard Leaching Test (KSLT) [16,20,21].

\begin{tabular}{|c|c|c|}
\hline & $\begin{array}{r}\text { TCLP } \\
\end{array}$ & KSLT \\
\hline Definition & $\begin{array}{l}\text { An analysis method to determine the } \\
\text { mobility of both organic and inorganic } \\
\text { analytes present in liquid, solid, and } \\
\text { multiphasic wastes }\end{array}$ & $\begin{array}{l}\text { A analysis method to predict } \\
\text { potential leaching level of } \\
\text { environmental contaminants from } \\
\text { industrial wastes after landfill }\end{array}$ \\
\hline Purpose & $\begin{array}{l}\text { To determine if a waste may meet the } \\
\text { definition of EP (Extraction } \\
\text { Procedure) Toxicity, that is, carrying a } \\
\text { hazardous waste code ( } 40 \text { CFR Part } \\
\text { 261) under Resource Conservation and } \\
\text { Recovery Act (RCRA) }\end{array}$ & $\begin{array}{l}\text { To determine if a waste is specified } \\
\text { over the regulation level of Korean } \\
\text { waste management act or which } \\
\text { landfill method is proper for a waste }\end{array}$ \\
\hline Target solid materials & $\begin{array}{l}\text { Materials are solid waste if they are } \\
\text { abandoned by being: (1) Disposed of; } \\
\text { or (2) Burned or incinerated; or ( } 3 \text { ) } \\
\text { Accumulated, stored, or treated (but } \\
\text { not recycled) before or in lieu of being } \\
\text { abandoned by being disposed of, } \\
\text { burned, or incinerated }\end{array}$ & $\begin{array}{l}\text { Slag, dust, sand blast, waste } \\
\text { refractory, incineration waste residue, } \\
\text { solidified/stabilized waste, waste } \\
\text { catalyst, waste absorbent/adsorbent, } \\
\text { wastewater sludge, etc. }\end{array}$ \\
\hline Sample treatment & Sieving into $9.5 \mathrm{~mm}$ & Sieving into $5.0-5.5 \mathrm{~mm}$ \\
\hline Extraction device & Rotary extraction device (30 rpm) & $\begin{array}{l}\text { Horizontal back-and-forth shaker } \\
(200 \mathrm{rpm})\end{array}$ \\
\hline Extraction time & $18 \mathrm{hr}$ & $6 \mathrm{hr}$ \\
\hline $\mathrm{pH}$ of extractant & $\begin{array}{l}\text { Fluid \#1: pH } 4.93 \pm 0.05 \\
\text { Fluid \#2: pH } 2.88 \pm 0.05\end{array}$ & $\begin{array}{l}\text { pH } 5.8-6.3 \text { adding } \mathrm{HCl} \text { to distilled } \\
\text { water }\end{array}$ \\
\hline Sample (g): Extractant (mL) & $1: 20$ & $1: 10$ \\
\hline $\begin{array}{l}\text { Separation of solid and } \\
\text { liquid }\end{array}$ & $\begin{array}{l}0.6-0.8 \mu \mathrm{m}-\mathrm{membrane} \text { filter or } \\
\text { centrifuge }\end{array}$ & $1 \mu \mathrm{m}$-membrane filter or centrifuge \\
\hline
\end{tabular}




\section{Results and Discussion}

\subsection{Physical and Chemical Characteristics of the Mine Tailings}

The mine tailings showed dark-gray coloration. The sample was in a slightly wet state containing 9.6\% water and its $\mathrm{pH}$ value was 7.5. The value of loss on ignition (LOI), which indicates the proportion of total organic matters, was $9.3 \%$ and organic carbon content among all organic matters was $3.9 \%$. Concentrations of anions in the mine tailings analyzed using IC are shown in Table 3 . Then, the concentrations of most anions $\left(\mathrm{F}^{-}, \mathrm{Cl}^{-}, \mathrm{NO}_{2}{ }^{-}, \mathrm{NO}_{3}{ }^{-}, \mathrm{Br}^{-}\right.$, and $\left.\mathrm{PO}_{4}{ }^{2-}\right)$ were very low, whereas the concentration of $\mathrm{SO}_{4}{ }^{2-}$ (sulfate: $224 \mathrm{mg} / \mathrm{L}$ ) was much higher than others. The high concentration of sulfate indicates that the oxidation of sulfide minerals had occurred in the mine tailings, so that sulfate had been produced. According to XRD analysis, the mine tailings mostly consist of quartz $\left(\mathrm{SiO}_{2}\right)$, kaolinite $\left(\mathrm{Al}_{2} \mathrm{Si}_{2} \mathrm{O}_{5}(\mathrm{OH})_{4}\right)$, jarosite $\left(\mathrm{KFe}_{3}(\mathrm{OH})_{6}\left(\mathrm{SO}_{4}\right)_{2}\right)$, pyrite $\left(\mathrm{FeS}_{2}\right)$ and ferric hydroxide $\left(\mathrm{Fe}(\mathrm{OH})_{3}\right)$.

Table 3. Physical and chemical properties of the mine tailings.

\begin{tabular}{lccc}
\hline Property & & Unit & Value \\
\hline $\mathrm{pH}$ & & $\%$ & $7.5 \pm 0.14$ \\
Water content & & $\%$ & $9.6 \pm 0.42$ \\
Loss on ignition (LOI) & $\%$ & $9.3 \pm 0.33$ \\
Organic carbon content & $\mathrm{mg} / \mathrm{L}$ & $3.9 \pm 0.15$ \\
& $\mathrm{~F}^{-}$ & $\mathrm{mg} / \mathrm{L}$ & 0.11 \\
& $\mathrm{Cl}^{-}$ & $\mathrm{mg} / \mathrm{L}$ & 20 \\
\multirow{3}{*}{ Anions } & $\mathrm{NO}^{-}$ & $\mathrm{mg} / \mathrm{L}$ & $\mathrm{ND}$ \\
& $\mathrm{NO}^{-}$ & $\mathrm{mg} / \mathrm{L}$ & 1.9 \\
& $\mathrm{Br}^{-}$ & $\mathrm{mg} / \mathrm{L}$ & 0.71 \\
& $\mathrm{PO}_{4}{ }^{2-}$ & $\mathrm{mg} / \mathrm{L}$ & 9.6 \\
& $\mathrm{SO}_{4}{ }^{2-}$ & $\mathrm{DD}$ & 224 \\
\hline
\end{tabular}

$\mathrm{ND}=$ Not Detected

\subsection{Total Concentrations of As and Heavy Metals in the Mine Tailings}

In order to measure total concentrations of As and heavy metals in the mine tailings, three standard USA and Korean methods were used: EPA method 6010, KST for soil, and KST for waste, as shown in Table 4 [15-17]. Total concentrations of As and heavy metals were significantly higher than Korean soil contamination criteria. This result indicates that the mine tailings were greatly contaminated and need appropriate treatments to prevent secondary contamination.

Total concentrations of As and heavy metals evaluated by EPA method 6010 and KST for waste were much higher than those evaluated by KST for soil. This result was consistent with that reported by Jung et al. [22]. In their study, extraction tests by $0.1 \mathrm{~N} \mathrm{HCl}$ solution (a similar method to KST for soil) and aqua regia (concentrated $\mathrm{HCl}$ and $\mathrm{HNO}_{3}$; a similar method to EPA method 6010 and $\mathrm{KST}$ for waste) were applied for determining total concentrations of heavy metals in mine wastes from several abandoned metalliferous mines in Korea. Then the concentrations of most heavy metals extracted by 
aqua regia were much higher than those by $0.1 \mathrm{~N} \mathrm{HCl}$, showing the similar tendency to our results. Another remarkable point observed in Table 4 is that, in particular, concentrations of $\mathrm{As}, \mathrm{Cu}, \mathrm{Pb}$, and Cd obtained by EPA method 6010 are very similar to those by KST for waste (e.g., As: 67,336 mg/kg by EPA method 6010 and $66,155 \mathrm{mg} / \mathrm{kg}$ by KST for waste). However, As concentration extracted by KST for soil was only $5 \%$ of those by other methods.

These results are attributed to methodological differences between the three standard methods as shown in Table 1 in "Experimental" section. In other words, both EPA method 6010 and KST for waste are to digest all metals in a sample with very strong acids by heating under boiling point. Whereas KST for soil is to just extract metals by shaking at $30{ }^{\circ} \mathrm{C}$ with acidic solutions and is appropriate to the determination of only available (extractable) metal concentrations in a sample. Our suggestion for the analysis of metal concentration by the KST for soil is, therefore, that it should be either defined as a method to determine only available (extractable) metal concentrations in the soil, or modified as the other two methods to determine total metal concentration in the soil.

Table 4. Total concentrations $(\mathrm{mg} / \mathrm{L})$ of arsenic (As) and heavy metals in the mine tailings compared to Korea soil contamination criteria (both acting and warning criteria).

\begin{tabular}{lccccccc} 
Metal & \multicolumn{3}{c}{ Standard method } & & \multicolumn{3}{c}{ Korean soil contamination criteria } \\
$(\mathbf{m g} / \mathbf{k g})$ & \multicolumn{3}{c}{} & & \multicolumn{2}{c}{ Acting } & \multicolumn{3}{c}{ Warning } \\
\cline { 2 - 7 } & EPA method 6010 & KST for soil & KST for waste & A area & B area & A area & B area \\
\hline $\mathrm{As}$ & $67,336 \pm 104$ & $3,068 \pm 22$ & $66,155 \pm 710$ & 15 & 50 & 6 & 20 \\
$\mathrm{Fe}$ & $137,180 \pm 756$ & & & $\mathrm{NE}$ & $\mathrm{NE}$ & $\mathrm{NE}$ & $\mathrm{NE}$ \\
$\mathrm{Cu}$ & $764 \pm 0.83$ & $233 \pm 1.67$ & $745 \pm 2$ & 125 & 500 & 50 & 200 \\
$\mathrm{~Pb}$ & $3,421 \pm 20$ & $875 \pm 3.1$ & $3,572 \pm 51$ & 300 & 1,000 & 100 & 400 \\
$\mathrm{Mn}$ & $24,256 \pm 31$ & & & $\mathrm{NE}$ & $\mathrm{NE}$ & $\mathrm{NE}$ & $\mathrm{NE}$ \\
$\mathrm{Cr}(\mathrm{VI})$ & $71.7 \pm 0.67$ & & $65 \pm 1.35$ & 10 & 30 & 4 & 12 \\
$\mathrm{Cd}$ & $54.4 \pm 0.09$ & $7.2 \pm 0.5$ & $56.3 \pm 0.3$ & 4 & 30 & 1.5 & 12 \\
$\mathrm{Zn}$ & $12,420 \pm 4.0$ & & & $\mathrm{NE}$ & $\mathrm{NE}$ & $\mathrm{NE}$ & $\mathrm{NE}$ \\
\hline
\end{tabular}

A area: farmland, ranch lot, school lot, park, etc.

$\mathrm{B}$ area: factory lot, railway, highway, etc.

$\mathrm{NE}=$ Not Established.

\subsection{Chemical Distribution of As in the Mine Tailings by Sequential Extraction}

Table 5 includes As contents, given in $\mathrm{mg} / \mathrm{L}$ leachate, $\mathrm{mg} / \mathrm{Kg}$ tailings, and \% of total content, obtained from each step and As minerals (both name and formula) which may be extractable at each step for the mine tailings extracted in the six step sequence developed by Herrewghe et al. [19]. Figure 2 shows the proportion of each As fraction for total $100 \%$. It is observed that most As in the mine tailings consists of the residual fraction $(89 \% ; 44,023 \mathrm{mg} / \mathrm{kg})$, which is assumed to represent As hosted by silicate or sulfide minerals and extracted by heating with concentrated strong acids. $\mathrm{NH}_{4} \mathrm{~F}$-extractable fraction, As bound to aluminum (Al), was then $1.4 \%(716 \mathrm{mg} / \mathrm{kg})$ and 
$\mathrm{NaOH}$-extractable fraction, As bound to iron $(\mathrm{Fe})$, was $8.7 \%(4,343 \mathrm{mg} / \mathrm{kg})$, whereas the easily soluble fraction, weakly sorbed non-ionic As fraction, was only $0.096 \%(48 \mathrm{mg} / \mathrm{kg})$. In this step, $\mathrm{As}_{2} \mathrm{O}_{3}(+\mathrm{III})$ and $\mathrm{As}_{2} \mathrm{O}_{5}(+\mathrm{V})$ in the mine tailings, which are hygroscopic, dissolve readily in the extractant; in particular they ionize into the forms of $\mathrm{H}_{2} \mathrm{AsO}_{3}{ }^{-}$and $\mathrm{HAsO}_{4}{ }^{2-}$ at the neutral or weak alkaline $\mathrm{pH}$, due to their ionization characteristic depending on $\mathrm{pH}$ as below equations 1-5 [23]. Also, Figure 3 illustrates that speciation characteristic of As depending on $\mathrm{pH}$ is associated with its Eh values [23].

$$
\begin{array}{rr}
\mathrm{As}(\mathrm{III}): \mathrm{H}_{3} \mathrm{AsO}_{3} \rightarrow \mathrm{H}^{+}+\mathrm{H}_{2} \mathrm{AsO}_{3}{ }^{-} & \mathrm{pK}_{\mathrm{a}}=9.22 \\
\mathrm{H}_{2} \mathrm{AsO}_{3}{ }^{-} \rightarrow \mathrm{H}^{+}+\mathrm{HAsO}_{3}{ }^{2-} & \mathrm{pK}_{\mathrm{a}}=12.3 \\
\mathrm{As}(\mathrm{V}): \mathrm{H}_{3} \mathrm{AsO}_{4} \rightarrow \mathrm{H}^{+}+\mathrm{H}_{2} \mathrm{AsO}_{4}{ }^{-} & \mathrm{pK}_{\mathrm{a}}=2.2 \\
\mathrm{H}_{2} \mathrm{AsO}_{4}{ }^{-} \rightarrow \mathrm{H}^{+}+\mathrm{HAsO}_{4}{ }^{2-} & \mathrm{pK}_{\mathrm{a}}=7.08 \\
\mathrm{HAsO}_{4}{ }^{2-} \rightarrow \mathrm{H}^{+}+\mathrm{AsO}_{4}{ }^{3-} & \mathrm{pK}_{\mathrm{a}}=11.5
\end{array}
$$

where, $\mathrm{pK}_{\mathrm{a}}$ is the $\mathrm{pH}$ at which the dissociation of the reactant reaches $50 \%$.

In terms of methodology of the As sequential extraction, results are representative of As only in a qualitative sense and may determine the amount of surface-bound As. It, however, does not indicate either the information on As species in relatively insoluble precipitates or the composition and geometry of adsorbed As complexes [18]. Based on the knowledge, these results shown in Table 5 should be considered as data for estimating the distribution of As fractions which can be extractable by the specified acidic and alkaline solutions.

On the other hand, it is observed that an order in the contents of the extractable fractions is $\mathrm{NaOH}\left(\right.$ Step 3) $>>\mathrm{NH}_{4} \mathrm{~F}\left(\right.$ Step 2) $>\mathrm{H}_{2} \mathrm{SO}_{4}\left(\right.$ Step 5) $>\mathrm{NH}_{4} \mathrm{Cl}$ (Step 1). This order is consistent with that from the sequential extraction of Montana soil (SRM 2710), a certified reference material [19]. For another discovery, Johnston and Barnard (1979) [24] found that As and phosphorous (P) react similarly when treated by solutions containing sulfate, fluoride, bicarbonate, hydroxide and hydrogen ions (the same solutions as those in our test), and demonstrated the same order between As and $\mathrm{P}$ extractions for test soils (western New York soils): $\mathrm{NaOH}>>\mathrm{H}_{2} \mathrm{SO}_{4}>\mathrm{NH}_{4} \mathrm{~F}>\mathrm{NH}_{4} \mathrm{Cl}$ [19]. However, the order of As concentration extracted by $\mathrm{NH}_{4} \mathrm{~F}$ and $\mathrm{H}_{2} \mathrm{SO}_{4}$ found in our study does not fit with that in the study of Johnston and Barnard [24]. For this issue, we can suggest the following reasons related to characteristics of As bound to $\mathrm{Ca}\left(\mathrm{H}_{2} \mathrm{SO}_{4}\right.$-extractable). Even though $\mathrm{As}$ and $\mathrm{P}$ are chemically very similar elements, As bound to $\mathrm{Ca}$ is far more soluble than $\mathrm{P}$ bound to $\mathrm{Ca}$, so it may not be always accurate to apply the same sequential extraction protocol for both As and P as Johnston and Barnard's study. Also, As bound to $\mathrm{Ca}$ is much more unstable than As bound to $\mathrm{Al}$ or Fe, so can be more soluble at $\mathrm{pH} \leq 10$. Consequently, As bound to Ca may already dissolve in one of easily soluble ( $\mathrm{pH} 7)$ or $\mathrm{NH}_{4} \mathrm{~F}$ extraction ( $\mathrm{pH}$ 8) due to redistribution phenomena, and it probably also arises from As bound to Fe oxides, which is dissolved by sodium citrate $+\mathrm{NaHCO}_{3}+\mathrm{Na}_{2} \mathrm{~S}_{2} \mathrm{O}_{4} \cdot 2 \mathrm{H}_{2} \mathrm{O}$ treatment [19]. For those reasons, Herrewghe et al. have been replaced the acid " $\mathrm{H}_{2} \mathrm{SO}_{4}$ " extraction step by an oxidizing extraction using $8.8 \mathrm{~mol} / \mathrm{L} \mathrm{H}_{2} \mathrm{O}_{2}$ [19]. 
Table 5. Results of arsenic (As) sequential extraction of the mine tailings, given in $\mathrm{mg} / \mathrm{L}$ leachate, $\mathrm{mg} / \mathrm{kg}$ tailings and \% of total content, according to As chemical fractions in specific six steps.

\begin{tabular}{|c|c|c|c|c|c|c|}
\hline \multirow[t]{2}{*}{ Step [19] } & \multirow[t]{2}{*}{ Extractant [19] } & \multirow[t]{2}{*}{$\begin{array}{l}\text { As chemical } \\
\text { fraction [19] }\end{array}$} & \multirow[t]{2}{*}{$\begin{array}{l}\text { Mineral (Formula) } \\
{[25]}\end{array}$} & \multicolumn{2}{|c|}{$\begin{array}{c}\text { As concentration } \\
\text { (Average) }\end{array}$} & \multirow[t]{2}{*}{$\begin{array}{l}\text { Proportion } \\
(\%)\end{array}$} \\
\hline & & & & $\begin{array}{l}\mathbf{m g} / \mathbf{L} \\
\text { leachate }\end{array}$ & $\begin{array}{l}\mathbf{m g} / \mathbf{k g} \\
\text { tailings }\end{array}$ & \\
\hline $\begin{array}{l}\text { 1. Easily } \\
\text { soluble }\end{array}$ & $\begin{array}{l}1 \mathrm{M} \mathrm{NH}_{4} \mathrm{Cl} \\
(\mathrm{pH} \mathrm{7})\end{array}$ & $\begin{array}{l}\text { Neutral (non-ionic) } \\
\text { As }\end{array}$ & $\begin{array}{l}\text { Arsenolite }\left(\mathrm{As}_{2} \mathrm{O}_{3}\right) \\
\text { Claudetite }\left(\mathrm{As}_{2} \mathrm{O}_{3}\right)\end{array}$ & 0.80 & 48 & 0.096 \\
\hline $\begin{array}{l}\text { 2. } \mathrm{NH}_{4} \mathrm{~F}- \\
\text { extractable }\end{array}$ & $\begin{array}{l}0.5 \mathrm{M} \mathrm{NH}_{4} \mathrm{~F} \\
(\mathrm{pH} 8)\end{array}$ & As bound to $\mathrm{Al}$ & $\begin{array}{l}\text { Mansfieldite } \\
\left(\mathrm{AlAsO}_{4} \cdot 2 \mathrm{H}_{2} \mathrm{O}\right)\end{array}$ & 12 & 716 & 1.4 \\
\hline $\begin{array}{l}\text { 3. } \mathrm{NaOH}- \\
\text { extractable }\end{array}$ & $\begin{array}{l}0.1 \mathrm{M} \mathrm{NaOH} \\
(\mathrm{pH} \mathrm{12})\end{array}$ & $\begin{array}{l}\text { As bound to Fe } \\
\text { (non-occluded As) }\end{array}$ & $\begin{array}{l}\text { Scorodite }\left(\mathrm{FeAsO}_{4} \cdot 2 \mathrm{H}_{2} \mathrm{O}\right) \\
\text { Symplesite } \\
\left(\mathrm{Fe}_{3}\left(\mathrm{AsO}_{4}\right)_{2} \cdot 8 \mathrm{H}_{2} \mathrm{O}\right)\end{array}$ & 89 & 4,343 & 8.7 \\
\hline 4. Reducible & $\begin{array}{l}0.5 \mathrm{M} \text { sodium } \\
\text { citrate }+1 \mathrm{M} \\
\mathrm{NaHCO}_{3}+0.5 \mathrm{~g} \\
\mathrm{Na}_{2} \mathrm{~S}_{2} \mathrm{O}_{4} \cdot 2 \mathrm{H}_{2} \mathrm{O}\end{array}$ & $\begin{array}{l}\text { As bound to Fe } \\
\text { oxide } \\
\text { (Occluded As) }\end{array}$ & $\begin{array}{l}\text { Kalfanite } \\
\left(\mathrm{Ca}_{2} \mathrm{Fe}_{3} \mathrm{O}_{2}\left(\mathrm{AsO}_{4}\right) \cdot 2 \mathrm{H}_{2} \mathrm{O}\right)\end{array}$ & 3.1 & 183 & 0.37 \\
\hline $\begin{array}{l}\text { 5. Acid } \\
\text { soluble }\end{array}$ & $\begin{array}{l}0.25 \mathrm{M} \mathrm{H}_{2} \mathrm{SO}_{4} \\
(\mathrm{pH} \mathrm{1})\end{array}$ & As bound to $\mathrm{Ca}$ & $\begin{array}{l}\text { Rauenthalite } \\
\left(\mathrm{Ca}_{3}\left(\mathrm{AsO}_{4}\right)_{2} \cdot 10 \mathrm{H}_{2} \mathrm{O}\right) \\
\text { Pharmacolite } \\
\left(\mathrm{Ca}\left(\mathrm{HAsO}_{4}\right) \cdot 2 \mathrm{H}_{2} \mathrm{O}\right)\end{array}$ & 7.3 & 435 & 0.87 \\
\hline 6. Residual & $\begin{array}{l}\mathrm{HCl}_{\text {conc }}+ \\
\mathrm{HNO}_{3 \text { conc }} \\
+\mathrm{HF}_{\text {conc }} \\
\end{array}$ & $\begin{array}{l}\text { As bound to silicate } \\
\text { and sulfide minerals }\end{array}$ & Arsenopyrite (FeAsS) & 440 & 44,023 & 89 \\
\hline
\end{tabular}

Figure 2. Chemical distribution of arsenic (As) in the mine tailings (Fraction $1<$ Fraction $4<$ Fraction $5<$ Fraction $2<$ Fraction $3<$ Fraction 6 ).

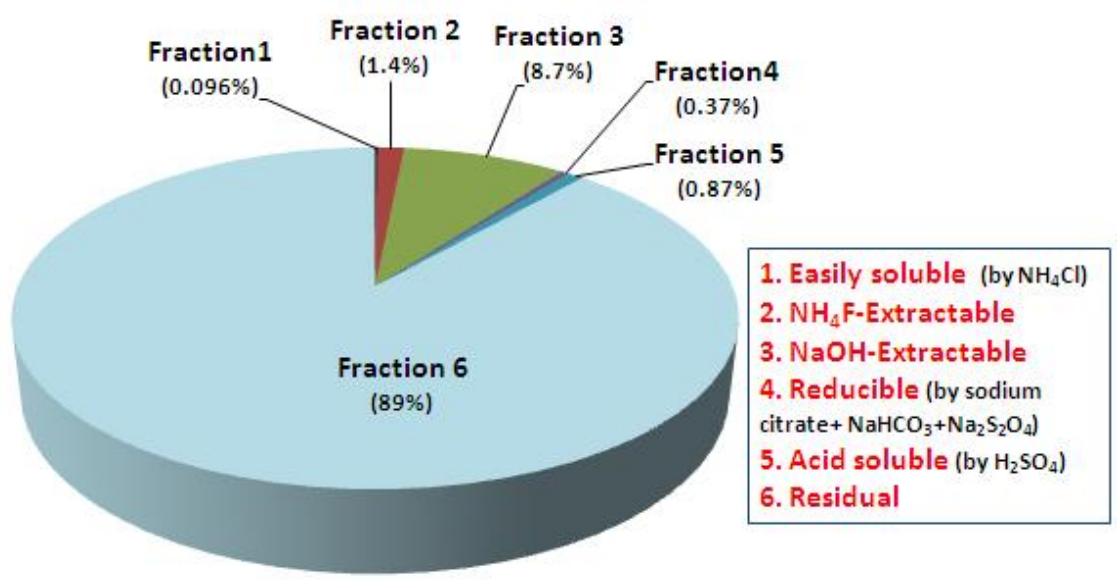


Figure 3. Speciation of arsenic (As) in water depending on $\mathrm{pH}$ (Eh: the oxidation/reduction potential (ORP) of the water) (modified from [23]).

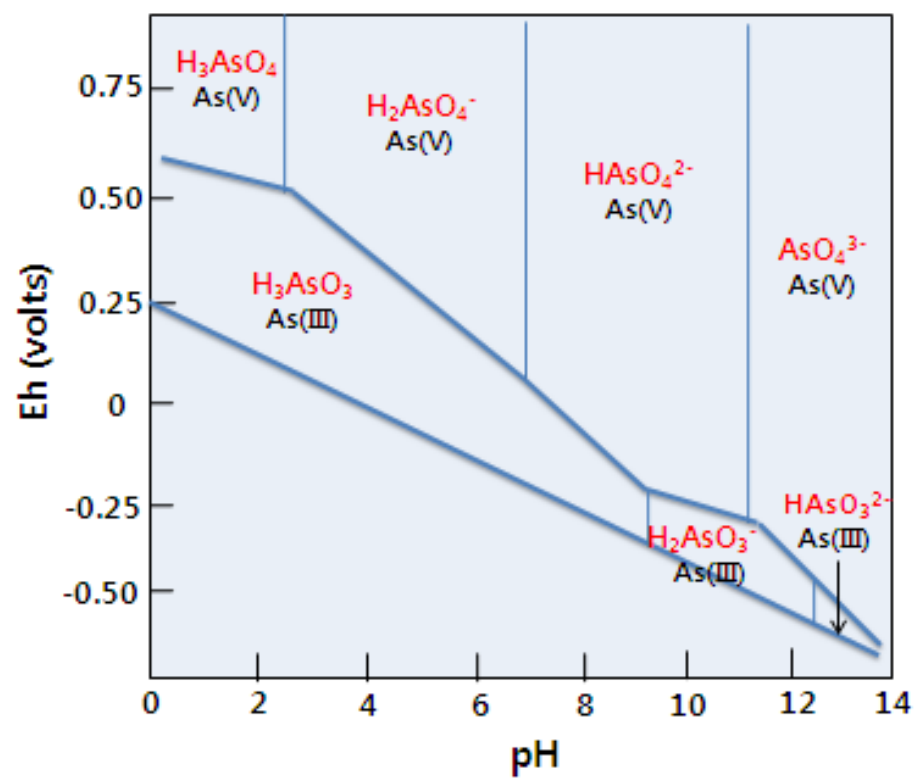

\subsection{Leaching of As and Heavy Metals from the Mine Tailings}

Leaching tests (TCLP and KSLT) of the mine tailings were performed to indirectly evaluate release and mobility of contaminants to the surrounding environment by normal rain (approx. $\mathrm{pH}$ 5.6) or acidic rain (under $\mathrm{pH}$ 5.6) [15,20]. According to TCLP, the $\mathrm{pH}$ of the solution produced by shaking the mine tailings with ultra-pure water was 7.21 and that of the solution acidified with $\mathrm{HCl}$ was 1.14, thus fluid \#1 ( $\mathrm{pH} 4.93 \pm 0.05)$ was selected for the leaching test.

Table 6 shows leaching concentrations of As and heavy metals by TCLP and KSLT, compared with their criteria. Leaching concentrations $(\mathrm{mg} / \mathrm{L})$ of As and heavy metals were much lower than the criteria [e.g., As (mg/L): 0.43 for TCLP and 0.24 for KSLT (cf. criteria (mg/L): 5.0 for TCLP and 1.5 for KSLT), $\mathrm{Pb}(\mathrm{mg} / \mathrm{L}): 0.15$ for TCLP and 0.10 for KSLT (cf. criteria (mg/L): 5.0 for TCLP and 3.0 for KSLT), Cr(VI) (mg/L): 0.42 for TCLP and 0.36 for KSLT (cf. criteria (mg/L): 5.0 for TCLP and 1.5 for KSLT)]. Especially, the leaching levels of As were in the range of $0.014-0.026 \%$, presenting only meager proportions for the total arsenic content in the mine tailings. Kim et al. [26] also reported a similar result on leaching of As from mine tailings. In their study, As leaching levels were in the range of $0.0017-0.37 \%$, when mine tailings of six types were mixed with water for $1 \mathrm{hr}$ at a ratio of 1:5 as mass [26]. Even though the test conditions such as leaching solution and shaking time do not correspond to those in our study, the result also satisfies that soluble As in water occupied only minor fraction of the total As in mine tailings.

In terms of only the leaching levels, current state of the mine tailings can be regarded as stable for release risk of As and heavy metals by acidic rain. Further, this sample can be classified into a nonhazardous waste group for landfill treatment. It is, however, suggested that the mine tailings need to be treated to meet Korean soil contamination criteria (see Table 4), if it is expected to return them to the environment as a part of the soil. 
The leaching concentrations of As in the both leaching tests $(0.43 \mathrm{mg} / \mathrm{L}$ for TCLP and $0.24 \mathrm{mg} / \mathrm{L}$ for KSLT) were lower than those of fraction 1 and 2 in the sequential extraction $(0.80 \mathrm{mg} / \mathrm{L}$ for fraction 1 and $12 \mathrm{mg} / \mathrm{L}$ for fraction 2) as shown in Table 7. For this result, we consider that the $\mathrm{pH}$ of each extractant presumably affected most greatly the As extraction reaction. Ghosh et al. [27] also reported that As leaching concentrations by TCLP was much less (10 times) than those by Landfill leachate (LL), and considered that the higher leachate $\mathrm{pH}$ (6.8) than that of TCLP (4.9) contributed to the result since As mobilization increases with $\mathrm{pH}$ increase. In addition, they commented that the TCLP is focused on only acidic conditions and poorly simulates alkaline $\mathrm{pH}$, low redox potential, biological activity, long retention time, and organic composition of mature landfills [27]. It is therefore concluded that leaching concentrations of As in the fraction 1 and 2 by the sequential extraction (weak alkaline $\mathrm{pH}$ ) were higher than those by TCLP and KSLT (weak acidic $\mathrm{pH}$ ) because more As leaches with higher $\mathrm{pH}$. Though, in the comparison of As leaching by TCLP and KSLT, TCLP with lower $\mathrm{pH}$ than KSLT showed very slightly higher As leaching and this result is attributed to other conditions such as the extraction time and the ratio of solid and liquid rather than the $\mathrm{pH}$ of extractant.

On the other hand, the possibility of As and heavy metals releases from the mine tailings at the natural site can be explained by comparing our study to those suggested by other studies $[3,28,29]$. The mine tailings used in this study were sampled from the surface of the tailings pile at the abandoned mine. Because mine tailings deposition had been ended before abandoning mining operation in 2001, the surface of uncovered mine tailings pile had been allowed to be in contact with oxygen. Those conditions resulted in the oxidation of sulfide minerals in the mine tailings, as shown in Figure 4 [28]. The oxidation of sulfide minerals which combine with As or heavy metals can also result in the dissolution of As and heavy metals by water [3]. Based on the presence of sulfide minerals, high contents of As and heavy metals, potential of oxygen contact, and high sulfate concentration in the mine tailings, the equations $6-8$ related to dissolution of iron and arsenic, as an example, could have occurred in the mine tailings [3-5,29]:

$$
\begin{gathered}
\mathrm{FeS}_{2}+7 / 2 \mathrm{O}_{2}+\mathrm{H}_{2} \mathrm{O} \rightarrow \mathrm{Fe}^{2+}+2 \mathrm{SO}_{4}{ }^{2-}+2 \mathrm{H}^{+} \\
\mathrm{Fe}_{(1-\mathrm{x})} \mathrm{S}+(2-\mathrm{x} / 2) \mathrm{O}_{2}+\mathrm{xH}_{2} \mathrm{O} \rightarrow(1-\mathrm{x}) \mathrm{Fe}^{2+}+\mathrm{SO}_{4}{ }^{2-}+2 \mathrm{xH}^{+} \\
4 \mathrm{FeAsS}+13 \mathrm{O}_{2}+6 \mathrm{H}_{2} \mathrm{O} \rightarrow 4 \mathrm{Fe}^{2+}+4 \mathrm{H}_{2} \mathrm{AsO}_{4}{ }^{-}+4 \mathrm{SO}_{4}{ }^{2-}+4 \mathrm{H}^{+}
\end{gathered}
$$

Here, ferrous ions precipitate in the form of ferric hydroxide by oxidizing or hydrating, as shown in the equation (9):

$$
\mathrm{Fe}^{2+}+1 / 4 \mathrm{O}_{2}+5 / 2 \mathrm{H}_{2} \mathrm{O} \rightarrow \mathrm{Fe}(\mathrm{OH})_{3}+2 \mathrm{H}^{+}
$$

Heavy metals released by oxidation can be re-adsorbed onto the surface of ferric hydroxide, and also adsorbed heavy metals can be separated from the surface of ferric hydroxide by water [30]. The low leaching concentration in the test indicates that easily soluble fraction of As and heavy metals might be already released by the oxidation of sulfide minerals with air and water for a long period at the tailings deposition site. Based on the potential that As and heavy metals could be already released from the mine tailing, investigations on the status of contaminants in nearby lands and groundwater are needed. 
Figure 4. Schematic of an uncovered tailings impoundment (modified from [28]).

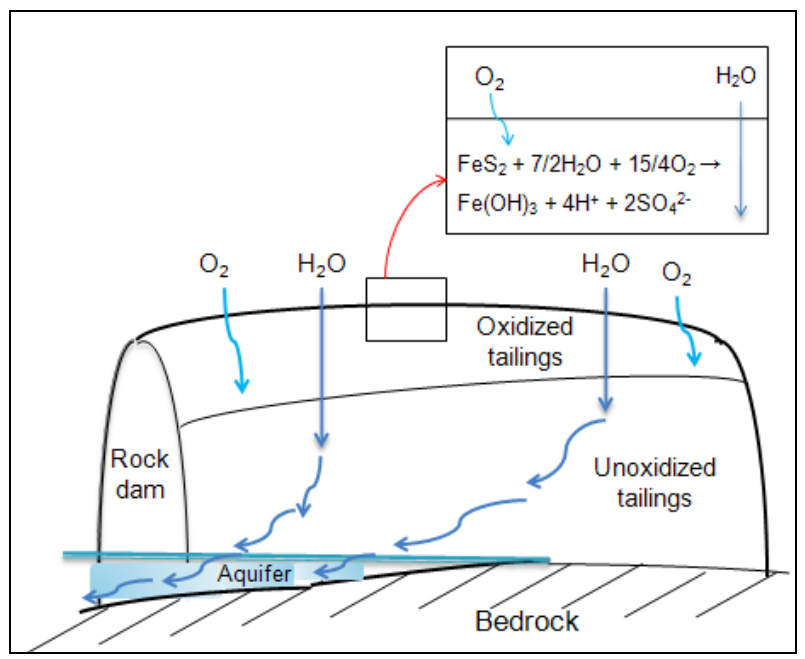

Table 6. Leaching concentrations ( $\mathrm{mg} / \mathrm{L})$ of arsenic (As) and heavy metals from the mine tailings tested by Toxicity Characteristic Leaching Procedure (TCLP) and Korean Standard Leaching Test (KSLT).

\begin{tabular}{lcccc}
\hline \multirow{2}{*}{ Metal } & \multicolumn{2}{c}{ Leaching level (mg/L) } & \multicolumn{2}{c}{ Criteria (mg/L) } \\
\cline { 2 - 5 } & TCLP (US EPA) & KSLT (Korea) & TCLP (US EPA) & KSLT (Korea) \\
\hline $\mathrm{As}$ & 0.43 & 0.24 & 5.0 & 1.5 \\
$\mathrm{~Pb}$ & 0.15 & 0.10 & 5.0 & 3.0 \\
$\mathrm{Cr}(\mathrm{VI})$ & 0.42 & 0.36 & 5.0 & 1.5 \\
$\mathrm{Cu}$ & 0.29 & 0.08 & $\mathrm{NE}$ & 3.0 \\
$\mathrm{Cd}$ & 0.20 & 0.19 & 1.0 & 0.3 \\
\hline
\end{tabular}

$\mathrm{NE}=$ Not Established

Table 7. Comparison of Arsenic (As) concentrations between Toxicity Characteristic Leaching Procedure (TCLP), Korean Standard Leaching Test (KSLT), and extractable fractions (fraction 1 and 2) in the As sequential extraction.

\begin{tabular}{|c|c|c|c|c|c|}
\hline \multirow{2}{*}{ Parameter } & \multirow{2}{*}{ Unit } & \multirow{2}{*}{ TCLP } & \multirow{2}{*}{ KSLT } & \multicolumn{2}{|c|}{ Sequential extraction } \\
\hline & & & & Fraction 1 & Fraction 2 \\
\hline $\mathrm{pH}$ of extractant & $\mathrm{pH}$ & 5 & 6 & 7 & 8 \\
\hline Extraction time & $\mathrm{hr}$ & 18 & 6 & 2 & 15 \\
\hline Solid (g):liquid (mL) & & $1: 20$ & $1: 10$ & $1: 60$ & $1: 60$ \\
\hline $\begin{array}{l}\text { As concentration in } \\
\text { leachant }\end{array}$ & $\mathrm{mg} / \mathrm{L}$ & 0.43 & 0.24 & 0.80 & 12 \\
\hline
\end{tabular}




\section{Conclusions}

The mine tailings were contaminated with much higher concentrations of As and heavy metals than the Korean soil contamination criteria. The measured concentrations were different depending on the test methods used. EPA method 6010 and KST for waste, digestion methods using strong acids and high temperature were more effective for total concentration analysis of As and heavy metals than KST for soil. In the mine tailings, As mostly consists of the residual fraction and the fractions extracted by alkaline extractants $\left(\mathrm{NH}_{4} \mathrm{Cl}\right.$ and $\left.\mathrm{NH}_{4} \mathrm{~F}\right)$ were meager. In TCLP and KSLT, concentrations of As and heavy metals released from the mine tailings were far lower than their criteria, indicating a non-hazardous waste. The leaching levels of As by TCLP and KSLP were lower than those of soluble fractions by the sequential extraction because of the difference of $\mathrm{pH}$ among the extractants in each test. In the further study, it is necessary to investigate contamination status of nearby soil and groundwater. In addition, mine tailings treatment is needed to prevent additional oxidation of sulfide minerals in mine tailings by oxygen contact and release of As and heavy metals by water.

\section{Acknowledgements}

This work was supported by the grant from the Energy Technology Innovation (ETI) R\&D Program in the Ministry of Knowledge Economy, Republic of Korea.

\section{References and Notes}

1. Roussel, C.; Bril, H.; Fernandez, A. Heavy metals in the environment. Arsenic speciation: involvement in evaluation of environmental impact caused by mine wastes. J. Environ. Qual. 2000, 29, 182-188.

2. Jang, M.; Hwang, J.S.; Choi, S.I.; Park, J.K. Remediation of arsenic-contaminated soils and washing effluents. Chemosphere 2005, 60, 344-354.

3. Kim, M.; Jung, Y. Vertical distribution and mobility of arsenic and heavy metals in and around mine tailings of an abandoned mine. J. Environ. Sci. Health Part A 2004, 39, 203-222.

4. Blowes, D.; Jambor, J.; Hanton-Fong, C.; Lortie, L.; Gould, W. Geochemical, mineralogical and microbiological characterization of a sulphide-bearing carbonate-rich gold-mine tailings impoundment, Joutel, Quebec. Appl. Geochem. 1998, 13, 687-705.

5. McGregor, R.; Blowes, D.; Jambor, J.; Robertson, W. The solid-phase controls on the mobility of heavy metals at the Copper Cliff tailings area, Sudbury, Ontario, Canada, J. Contam. Hydrol. 1998, 33, 247-271.

6. Lee, M.; Paik, I.; Kim, I.; Kang, H.; Lee, S. Remediation of heavy metal contaminated groundwater originated from abandoned mine using lime and calcium carbonate. J. Hazar. Mater. 2007, 144, 208-214.

7. Korean Ministry of Environment. Final report on soil environment control actions of abandoned metal mines. Korean Ministry of Environment: Gwachen, Gyeonggi-do, Korea, 2007.

8. Cline, S.R.; Reed, B.E. Lead removal from soils via bench-scale soil washing techniques. $J$. Environ. Engin. 1995, 121, 700-705. 
9. Sirguey, C.; de Souza e Silva, P.T.; Schwartz, C.; Simonnot, M-O. Impact of chemical oxidation on soil quality. Chemosphere 2008, 72, 282-289.

10. Basha, E.A.; Hashim, R.; Mahmud, H.B.; Muntohar, A.S. Stabilization of residual soil with rice husk ash and cement. Construc. Build. Mater. 2005, 19, 448-453.

11. Del Panno, M.T.; Morelli, I.S.; Engelen, B.; Corti, L.B. Effect of petrochemical sludge concentrations on microbial communities during soil bioremediation. FEMS Microbio. Ecolo. 2005, 53, 305-316.

12. Ahn, J.W.; Cho, H.C.; You, K.S.; Han, G.C.; Um, N.I. Characteristics of carbonation reaction from municipal solid waste incinerator bottom ash as a function of water content and their effect on the stabilization of copper and lead. Mater. Sci. Forum 2007, 544, 533-536.

13. Bertos, M. Fernandez; Simons, S.J.R.; Hills, C.D.; Carey, P.J. A review of accelerated carbonation technology in the treatment of cement-based materials and sequestration of $\mathrm{CO}_{2} . J$. Hazar. Mater. 2004, 112, 193-205.

14. Melton, J.S.; Tarabadkar, K.; Kevin, G. Accelerated Carbonation of Contaminated Soils for Beneficial Use Applications; Executive Summary of Project 34, Univ. of New Hampshire, Durham, NH, USA, 2008.

15. Korean Ministry of Environment, Nov. 2004 (No. 2004-185), Waste Standard Test, Waste Management Act. Korean Ministry of Environment: Gwachen, Gyeonggi-do, Korea, 2004.

16. EPA method 6010, Compilation of EPA's Sampling and Analysis Methods, 2nd ed.; Section A, CRC press, Lewis Publishers, Inc, New York, NY, USA, 1998.

17. Korean Ministry of Environment, July 2008 (No. 2008-115), Soil Environment Standard Test, Soil Environment Preservation Act.

18. Wang, S.; Mulligan, C.N. Speciation and surface structure of inorganic arsenic in solid phases: A review. Environ. Intern. 2008, 34, 867-879.

19. Herreweghe, S.V.; Swennen, R.; Vandecasteele, C.; Cappuyns, V. Solid phase speciation of arsenic by sequential extraction in standard reference materials and industrially contaminated soil samples. Environ. Pollut. 2003, 122, 323-342.

20. EPA Test Method 1311-TCLP, Toxicity Characteristic Leaching Procedure; Available online: http://www.ehso.com (accessed August 10, 2009).

21. Part 261-Identification and listing of hazardous wastes. Available online: http://www.ehso.com/ Regfiles/40p0261.pdf (accessed September 29, 2009).

22. Jung, M.; Ahn, J.; Chon, H. Environmental contamination and sequential extraction of trace elements from mine wastes around various metalliferrous mines in Korea. Geosystem Eng. 2001, 4, 50-60.

23. Kartinen, E.O.; Martin, C.J. An overview of arsenic removal processes. Desalination 1995, 103, 79-88.

24. Johnston, S.E.; Barnard, W. Comparative effectiveness of fourteen solutions for extracting arsenic form four Western New York soils. Soil Sci. Soc. Am. J. 1979, 43, 304-308.

25. Drahota, P.; Filippi, M. Secondary arsenic minerals in the environment: A review. Environ. Intern. 2009, 35, 1243-1255.

26. Kim, M.; Ahn, K.; Jung, Y. Distribution of inorganic species in mine tailings of abandoned mines from Korea. Chemosphere 2000, 49, 307-312. 
27. Ghosh, A.; Mukiibi, M.; Ela, W. TCLP underestimates leaching of arsenic from solid residuals under landfill conditions. Environ. Sci. Technol. 2004, 38, 4677-4682.

28. Ribit, I.; Ptacek, C.; Blowes, D.; Jambor, J. The potential for metal release by reductive dissolution of weathered mine tailings. J. Contam. Hydrol. 1995, 17, 239-273.

29. Johnson, R.; Blowes, D.; Robertson, W.; Jambor, J. The hydrogeochemistry of the Nickel Rim mine tailings impoundment, Sudbury, Ontario. J. Contam. Hydrol. 2000, 41, 49-80.

30. Holmstrom, H.; Ljungberg, J.; Ekstrom, M.; Ohlander, B. Secondary copper enrichment in tailings at the Laver mine, northern Sweden. Environ. Geol. 1999, 38, 327-342.

(C) 2009 by the authors; licensee Molecular Diversity Preservation International, Basel, Switzerland. This article is an open-access article distributed under the terms and conditions of the Creative Commons Attribution license (http://creativecommons.org/licenses/by/3.0/). 